\title{
ANALYSIS OF THE IMPACT OF ARABIC-MALAY BILINGUAL DICTIONARIES IN MALAYSIA
}

\author{
Hanafi Dollah, ${ }^{\mathrm{a} * *}$ Alfa Muhammed Salisu ${ }^{\mathrm{b}}$, Nurazzelena Abdullah $^{\mathrm{c}}$ \\ ${ }^{a}$ Department of Arabic Language and Literature, International Islamic University Malaysia \\ ${ }^{b}$ Department of Arabic Language and Literature, International Islamic University Malaysia \\ ${ }^{c}$ Centre for Languages and Pre-University Academic Development (CELPAD), International Islamic University Malaysia. \\ *Corresponding author: farisnorhanafi@gmail.com
}

\section{Article history}

Received: 19/01/2015
Received in revised form: 31/03/2015
Accepted: 28/04/2015

\begin{abstract}
Abstrak
The emergence of Arabic language and Islamic religion in the Malay Archipelago which comprises the present day Malaysia, Singapore, Indonesia, Brunei Darussalam, part of the Philippines as well as southern Thailand gave birth to Islamic education through the medium of Arabic language. This was inevitable because of the mutual relationship between Arabic language and Islam. To have better understanding of the Quran as the primary source of Islam is to have mastery of Arabic language. Hence the Muslim scholars in the Malay Archipelago resorted to the writing of Arabic Malay dictionaries which could help in the proper understanding of Arabic texts such as the Quran and Hadith which were primarily in Arabic language. This effort continues from generation to another until modern times which gave rise to the production of different types of Arabic Malay bilingual dictionaries. Some of these dictionaries have contributed to the general education of the Malays for their precision in translation. This study however, is an attempt to examine and analyse the contributions of selected Malay Arabic dictionaries to the Malay world in order to determine their precision in translation from Arabic to Malay language with reference to their methodologies with the aim of suggesting standards by which an ideal and all-encompassing Arabic Malay bilingual dictionary could emerge.
\end{abstract}

Keywords: Analysis, Impact, Arabic-Malay, Bilingual Dictionaries, Archipelago. 


\subsection{INTRODUCTION}

The revelation of the Quran to the Prophet of Islam adopted standard Arabic from amongst the cluster of dialects of the time and thus became the language of Islam. Arabic language outside the shore of Arabian Peninsula therefore is concomitant to the emergence of Islam in such area (Alfa et al., 2014). It is a common knowledge that the main factor responsible for the spread and subsequently learning of Arabic language and literature outside Arabian Peninsula is Islam. Being the language of the Quran, its learning especially for ritual purposes, formed the basis of Islamic education. Hence, Islamic educational framework is embedded in Arabic language. Learning Arabic thus, is a pre-requisite to better understanding of Islam. That is the reason why Muslim scholars then-and up till today- consider Arabic learning as an integral aspect of Islam. Great scholars such as Imam Ibn Taymiyah, was of the opinion that Arabic Education is obligatory when he says: "indeed Arabic language is integral part of Islam; its learning is a compulsory obligation. In as much as the understanding of the Quran, and prophetic tradition, are not only compulsory but also neither could be understood without Arabic language. Hence, learning Arabic is compulsory, since every means directed towards an obligation, is obligatory in itself, such a means is obligatory" (Al Ba'lee, $1422 \mathrm{~A} . \mathrm{H}$ ).

However, it was asserted that Arabic language and Islam came to the Malay Archipelago ${ }^{1}$ as early as in the $7^{\text {th }}$ century with the aid of Arab Muslim preachers as well as traders. But it is very difficult to state precisely when it arrived due to the fact that there was no written evidence that could certify its veracity. However, there were historical facts and physical evidence that could prove the long history of Islam in this part of the world. Among them is a stone inscription of Arabic letters which was found at a spot twenty miles up the Terengganu River in the present day Malaysia. The stone, inscribed with Arabic letters was found dating as far back as 1386 A.D. According to other sources it was even as early as 1326 A.D. Therefore, the arrival of Islam was synchronous to the arrival of Arabic language (Kamal, H.M, 2004) due to the fact that the Arabs amongst those who introduced Islam in the Malay Archipelago did not only propagate Islamic teachings but also brought Arabic language that has a very close connection to the religion of Islam.

It is clear that the spread of Islam was greatly enhanced in the Archipelago by commercial contacts between the Arabs and the locals as a result of trade that existed between the Arabs and the Malay Kingdoms. It was also believed that some commercial contacts had existed between the Arab traders and China even before Islam where the Arab traders traversed the Malay Archipelago en route China. Hence, there was a need for communication between the local traders and their Arab counterparts. But more importantly still, there were inter marriages between the Arabs and local women from that time which brought the people in so much contact with Arabic language and it became a part of their culture. Therefore, the need for mastery of Arabic language skills -speaking, listening, reading and writingincreased with the passage of time. This brought about the idea of what could help in the understanding and mastery of the language which metamorphosed into the need for bilingual and multilingual dictionaries.

However, the study of the arrival of Islam to Malay Archipelago and history of the emergence of Arabic Malay dictionary raised an important issue as there is a big gap between the two histories. Most historians agreed that Islam came to the Malay Archipelago as early as the $14^{\text {th }}$ century. Some of them even said that Islam came to this peninsula in the $7^{\text {th }}$ century. Meanwhile, the successful effort in translating Arabic dictionary to the Malay language was only known in the $20^{\text {th }}$ century after the compilation of Qamus al-Marbawi. The gap thus raised several questions that require further explanations; whether the Malays had never thought of translating the Quran or the Arabic language to their native language except after 600 years or more after the arrival of Islam, or could there be some factors that constrained them from developing their talent, ideas and knowledge.

\footnotetext{
${ }^{1}$ Malay Archipelago is a collection or chain of islands which comprise of the present Malaysia, Singapore, Indonesia, Brunei Darussalam, Southern Thailand and part of the Philippines.
} 
Therefore, this study which is based on a fundamental and analytical approach is aimed at identifying the contributions of Arabic Malay Dictionaries and examining socio-economic, political and intellectual factors that might have contributed to the emergence of writing and compilation of those dictionaries. In modern times, the translation activities have been continued with the writing and publishing of numerous books and dictionaries the scholars. In order to develop and upgrade those dictionaries, further studies have also been carried out to look into various aspects of those dictionaries such as their semantic, lexical, grammatical and phonetic information, etc. This study is carried out on selected Arabic-Malay bilingual dictionaries in Malaysia using evaluation, analytical, statistical and descriptive methodology. The dictionaries selected for this study are Kamus Arab Melayu Dewan, Kamus Kontekstual al-Khalil and Qamus al-Marbawi. The significance and contributions of these Arabic Malay dictionaries to the Malay civilization are also highlighted.

\subsection{AIMS AND OBJECTIVES}

The present study is an attempt to analyze the contributions and significance of Arabic Malay bilingual dictionaries to the Malay civilization and education in Malaysia. It also evaluates the extent of precision in translation and the methodologies applied in the production of these linguistic apparatus with the aim of suggesting standards by which an ideal and more precise Arabic Malay bilingual dictionaries could emerge. This could also assist researchers in the area of Quranic translation to Malay language to be precise and accurate in their works of translation.

\subsection{PROBLEM STATEMENT}

In spite of having a long history between the Malay Kingdoms and Arabic language, the first known Arabic Malay bilingual dictionary, viz. Qamus al-Marbawi was only compiled in the 19th century. Since then efforts has been made to improve upon this dictionary which gave rise to a number of Arabic Malay bilingual dictionaries that had assisted significantly in improving the Malay civilization over the years. However, some of these dictionaries differ from one another in the context of translation. Therefore, there is a need to address their similarities and differences in order to know the extent of their accuracy in translation from the source language -Arabic- to the target language -Malay. This is carried out with the aim of setting a standard upon which future researchers can improve the current dictionaries.

\subsection{METHODOLOGY}

Three Arabic Malay dictionaries published in Malaysia, namely Qamus al-Marbawi, Kamus Arab Melayu Dewan and Kamus Kontekstual al-Khalil are selected for the purpose of analysis and evaluation of their translation and the precision in terms of translation. These dictionaries are statistically analysed and evaluated in order to have a clear statistics of how many Arabic words have already entered the Malay lexicography. The study is an attempt to examine the extent to which the Malay translations meet the meaning given in its original language which is Arabic as well other aspects of those dictionaries. This study is significant in upgrading the present Arabic Malay bilingual dictionaries in Malaysia as well as suggesting ways by which a more purposeful Arabic Malay lexicography in Malaysia could be improved.

\subsection{THE EMERGENCE AND DEVELOPMENT OF ARABIC DICTIONARY}

The history of lexicography is of trial and error, but lexicon is as old as writing itself. The Sumerians' signs on clay tablets constitute, perhaps, the world's first classified vocabularies. The Assyrians' coming to Babylon stimulated lexicography there. In fact, the germ of dictionary idea evolved 
in Assyria nearly a thousand years before Christ. The first Chinese essay in lexicography may be as old as the Assyrians. But systematic definition of a large number of characters was the Chinese Erh Ya which may be dated back to between 200 B.C. and the birth of Christ. It was in reality classified vocabulary. The earliest dictionary extant is Hsu Shen's "Shuo Wen" also in Chinese written in the first century A.D. It sets out canonical treatises and so has a parallel with early Arabic lexicography which was an aid to the understanding of the Quran and Hadith. Later, the Chinese type of lexicography included characters grouped phonetically irrespective of their varied written forms. Grammar lexicography later became prominent in both Sanskrit and Greek. In Greece, Aristarchus of Samothrace (220-145B.C.) was the first to divide words into eight parts based on philosophical ideas. This was to have later effects on Latin and Arabic (Fatai, O.J, 2014).

The Romans took their linguistic ideas from the Greeks, but judging by extant works, they did not compile alphabetical dictionaries. The greatest monument in Latin lexicography is Varro's "De lingua Latina" which is a discussion of words, not a dictionary. The author lived to 27 B.C. (Akhidime, J.A.F, 1979).

However, as far as lexicography is concerned there had been various attempts to make relatively small collections of rare words or write short monographs on some types of special vocabulary, before the magnificent attempt of the genius Arab Basran al-Khalil (d.170A.H.) to encompass all the roots (not the derivatives) of the language in one single lexicon, called al-'Ayn (after the Arabic letter 'ayn with which the lexicon begins). Darwish states that the analytical and mathematical mentality of al-Khalil brought him to the conclusion that no number of these monographs would suffice to comprehend all the roots in the language. Besides, such monographs are bound to be full of repetitions. Al-Khalil, therefore, set his mind to invent a system which would be both comprehensive and free from repetition; he came out successful, and gave us Kitab al-'Ayn which John Haywood described as a landmark not only of Arabic lexicography, but in the history of world lexicography (Haywood J.A, 1960). The purpose of al-Khalil's work, as stated in the introduction, was that "through it, the Arabs should be known by means of their poetry, proverbs and discourse in an unequivocal manner". As for the method followed, the introduction also states that he "compiled it on the letters of alif, $b a$ ', $t a$ ' containing what the Arabs spoke in the range of their speech and expressions, without deviation (Fatai O.J, 2014).

The idea upon which al-Khalil based his comprehensive non-repetitive lexicon is sometimes called 'the theory of roots', sometimes the permutative and sometimes the anagrammatical arrangement. To explain it in its simplest form, let us take a common tri-consonantal Arabic root r, k, b. By permutation, these three radicals theoretically can produce six forms: rkb, rbk, brk, bkr, krb, kbr.

Arabic dictionaries are, basically, of three types; monolingual, bilingual and multilingual dictionaries. The Arabic monolingual dictionary aims at explaining meanings of words or their definitions by using the same language such as Arabic-Arabic. The explanation of the meaning is always supported by authentic Arabic sources and evidences from the Quran, Hadith literatures, or classical Arabic poetry. The bilingual dictionary, on the other hand, has its entries in one language and the meanings and explanation in another. This kind of dictionary is essential for translation works such as Arabic - English, Arabic - French). However, the multilingual dictionary has the meanings and explanations given in more than one language such as Arabic - English - Malay.

\subsection{THE EMERGENCE AND CONTRIBUTIONS OF ARABIC-MALAY LEXICOGRAPHY}

A bilingual dictionary or translation dictionary is a specialized dictionary used to translate words or phrases from one language to another. Bilingual dictionaries can be unidirectional, meaning that they list the meanings of words of one language in another, or can be bidirectional, allowing translation to and from both languages. Bidirectional bilingual dictionaries usually consist of two sections, each listing words and phrases of one language alphabetically along with their translation. In addition to the 
translation, a bilingual dictionary usually indicates the part of speech, gender, verb type, declension model and other grammatical clues to help a non-native speaker to use the word. Other features occasionally present in bilingual dictionaries are lists of phrases, usage and style guides, verb tables, maps and grammar references. In contrast to the bilingual dictionary, a monolingual dictionary defines words and phrases instead of translating them (Nielson, S, 2010).

Significantly, there are two factors responsible for the emergence of Arabic-Malay bilingual dictionaries; religious -Islam and social factors.

The idea of compiling Arabic-Malay dictionaries arose due to the need of the Malays in understanding and explaining Quranic and Hadith literatures, and other Islamic books which were produced primarily in Arabic language. Hence the Arabic Language which is the key to the Quran and Hadith played the utmost important role in compiling these dictionaries. This is supported by the fact that since the arrival of Islam in the Malay Archipelago, it became part of the culture to study the Quran as well as the Hadith literatures in their source language. In addition to that, the earliest books written by the Malay scholars were concerned about the Quran and Hadith, and most of them were translated from Arabic books and manuscripts. Sheikh Daud al Fatani was among the pioneers in this area. Furthermore, a cursory look at early Malay authorships such as tafseer, fiqh, tasawwuf, grammar, reading etc. are all pointers to proper and in-depth understanding of the contents of the Quran.

Social factors were also considered in the authorship of Arabic Malay dictionaries in recent times due to the complexity of the contemporary society. The need to understand foreign language became necessary in Malaysia for so many reasons. Tourism, international relation, journalism, translation etc. brought the need for mastery of foreign languages especially Arabic. In Malaysia, for instance, the government cannot underestimate the need for Arabic language because of the patronage it enjoys from the Arab tourists in recent years. It was reported that Arab tourists spend between 20 to 30 billion dollars annually since 2002 (Al Atheer, 2013). According to Ahmad Al-Jahsyi, overseas director and tourism consul of Tourism Malaysia for Saudi Arabia, Yemen, the Levant and North Africa; more than 73,000 Saudis visited Malaysia between January and September 2013 (Habib S., 2014). Hence, vocabularies needed to communicate with members of the Arab communities and the ability to interact with the Arabs became necessary.

Therefore, there is no doubt that the Arabic Malay bilingual dictionary has much contributions to the Malay civilization. It then became a valuable treasure of the Malay heritage, a source of getting closer to the Arab culture and an instrument of ideas and creative thinking.

However, some of the factors that were responsible for the late emergence of this dictionary among the Malay scholars may not be far from the domination of traditional method of education that was prevalent in the early period. Acquisition of knowledge, then, was majorly through listening. Students were not trained to be creative but to depend on the little available materials while others concentrate on memorization or rote learning. In fact, before the arrival of Islam, the early Malays were mostly illiterate and they did not even have their own civilization. They were on the other hand influenced by other civilizations such as Hinduism and Buddhism. They also borrowed the Sanskrit letter in their writing. But when Islam came they changed the Sanskrit letter to the Jawi script, which originated from Arabic. It was then adapted to suit spoken classical Malay and is written from right to left and has six sounds not found in Arabic viz $c a, p a, g a, n g a, v a$, and nya. Since that time they gradually changed the previous culture to new Islamic one. Prior to it, their circumstances of ignorance were just like the Arab before Islam where the compilation of knowledge and sciences only took place during the Umayyad dynasty and later developed during the Abbasid dynasty (Snedon, 2003).

In Malaysia, Qamus al-Marbawi is considered very important and famous as it is widespread throughout the Malay world. In fact, it was also used by the Malay communities in Makkah, Egypt and some other parts of the world. Qamus al-Marbawi was written by a famous Malay scholar Sheikh Muhammad Idris al-Marbawi in the early twenties. Prior to this, there were other dictionaries written but not as popular as Qamus al-Marbawi. This dictionary has a special place in the field of lexicography for 
it was written in Jawi script and up to 36000 words has been translated from Arabic to Malay. All the words are arranged in alphabetical order. In this work, al-Marbawi made references to some Malay bilingual dictionaries such as Kamus Melayu Inggeris by R.J. Wilkinson and Buku Daftar Ejaan Melayu Rumi by Zaaba. Therefore al Marbawi's work still serve as a monumental effort in Malaysia and the Malay world in general.

\subsection{ARABIC MALAY LEXICOGRAPHY}

\subsection{The Malay Language}

Malay is used to describe the language and people who speak the Malay language. Malay language also known locally as Bahasa Melayu, is an Austronesian language spoken by the Malay people who are the native of the Malay Peninsula, Southern Thailand, Singapore, and parts of Sumatra. It is the official language of Malaysia and Brunei and one of the four official languages of Singapore. It is also used as a working language in East Timor. The official standard for Malay, as agreed upon by Indonesia, Malaysia and Brunei, is Bahasa Riau, the language of the Riau Archipelago, long considered the birthplace of the Malay language. In Malaysia, it is known as Bahasa Melayu or Bahasa Malaysia, which mean Malay, or Malaysian language. The later was introduced by the National Language Act 1967, was predominant until the 1990s, when most academics and government officials reverted to the older term, which is used in the Malay version of the Federal Constitution. Indonesia adopted a form of Malay as its official language upon independence, naming it Bahasa Indonesia. In Singapore and Brunei it is known simply as Malay or Bahasa Melayu. The reason for adopting these terms is political rather than a reflection of linguistic distinctiveness, as standard Bahasa Malaysia and Bahasa Indonesia are largely mutually intelligible versions of the same language. However, many Malay dialects are not as mutually intelligible: e.g. Kelantanese pronunciation is difficult even for some Malaysians to understand, while Javanese Malay tends to have a lot of unique words which are unfamiliar to other speakers of Malay. The language spoken by the Peranakan (Straits Chinese, a hybrid of Chinese settlers from the Ming Dynasty and local Malays) is a unique patois of Malay and the Chinese Dialect of Hokkien, which is mostly spoken in the former Straits Settlements of Penang and Malacca. The use of this interesting language is dying out however, with the Peranakan now choosing to speak either Hokkien or English. Malay is an agglutinative language, meaning that the meaning of the word can be changed by adding the necessary prefixes or suffixes. Root words are either nouns or verbs, e.g. masak (to cook) yields memasak (cooks, is cooking, etc.), memasakkan (cooks, is cooking, etc. [something]), dimasak (cooked - passive) as well as pemasak (cook person), masakan (cooking, cookery). Many initial consonants undergo mutation when prefixes are added: e.g. sapu (sweep) becomes penyapu (broom); panggil (to call) becomes memanggil (calls, is calling, etc.), tapis (sieve) becomes menapis (sieves, is sieving, etc.) (Nik Safiah Karim, 1997).

Prior to the British colonization, the Jawi script was adopted using Arabic letters for a long period of time as an official writing of this country. However, later it was replaced by the Latin alphabets. The impact of colonization was not only seen in the writing system, but in many aspects of language such as syntax and morphology of the Malay Grammar. For example, the term 'Nahu Bahasa Melayu' was widely used to refer to the Malay Grammar but it was then changed to Tatabahasa Melayu. The term 'Nahu' originated from Arabic while 'Tatabahasa' was taken from Sanskrit. According to Zaaba, there were three parts of speech in the Malay Language which are: noun, verb and preposition, just like Arabic. But later, the parts of speech were known to be four including adjective (Nik Safiah Karim, 1997).

It is mentioned before that Qamus al-Marbawi was considered as one of the best Arabic Malay dictionary in Malaysia before other Arabic Malay dictionaries were produced by the Malay scholars. Qamus al-Marbawi remains outstanding for its alphabetical arrangement based on trilateral root words.

For instance, the table below shows the statistics of transitive and intransitive Arabic unaffixed trilateral verbs in the selected dictionaries - Qamus al-Marbawi, Kamus Arab Melayu Dewan and Kamus Kontekstual al-Khalil. 
Table 1: Transitive and Intransitive Arabic Unaffixed Trilateral Verbs in the Selected Dictionaries

\begin{tabular}{|l|c|c|c|c|}
\hline Dictionary & $\begin{array}{c}\text { Transitive } \\
\text { verbs }\end{array}$ & $\begin{array}{c}\text { Intransitive } \\
\text { verbs }\end{array}$ & $\begin{array}{c}\text { Verbs used as } \\
\text { transitive and } \\
\text { intransitive }\end{array}$ & Total \\
\hline Qamus al-Marbawi & 612 & 1085 & 767 & 2464 \\
\hline Kamus Arab Melayu Dewan & 1412 & 3066 & 1481 & 5959 \\
\hline Kamus Kontekstual al- Khalil & 1535 & 3222 & 1479 & 6236 \\
\hline
\end{tabular}

The above table shows that more than 6000 root words were translated from Arabic to Malay language. The statistics indicate that the unaffixed trilateral verbs in Qamus al-Marbawi do not represent the majority of Arabic verbs. They also indicate that the transitive verbs comprise the majority of all the entries. This report is an important evidence that shows the extent to which Arabic verbs have penetrated the Malay lexicography due to borrowing.

A cursory look at the methodologies adopted in the translation of these dictionaries, attention is drawn to some important aspect of the scholarly efforts. They serve as reference to syntactical, morphological and lexical as well as phonetic apparatus in Malay language. During translation process, it seems quite difficult for translators to find exact meanings of some words that could give accurate and precise meaning of words in its first language. Here, phrases are often used. However, with the progress in Arabic lexicography, these problems have been somewhat overcome where the meanings given are almost accurate with the context, by giving consideration to the lexical, syntactical and morphological meaning of each. The lexical meaning is always referred to the meaning of the term in common usage. However, the common usage of a word may not enable a person to have a clear idea of the meaning he is looking for, because the meaning of the word might vary in context.

Arabic verbs are very unique in terms of its meaning and functions. Some intransitive verbs are used to refer to adjective, colours, physical characteristic, etc. Failure to understand this concept of verbs might lead to misunderstanding or misinterpreting the Arabic text or discourse as well as religious text such as Quran and Hadith literatures. A selected group of words can give insight to how the three bilingual dictionaries translated them in their own unique ways. For instance, some adjectives used to refer to colours are derived from intransitive verbs.

Table 2: Meaning of some intransitive verbs in the three selected Arabic Malay dictionaries in Malaysia

\begin{tabular}{|c|c|c|c|c|}
\hline $\begin{array}{l}\text { Kamus } \\
\text { Arab } \\
\text { Melayu } \\
\text { Dewan }\end{array}$ & $\begin{array}{l}\text { Kamus } \\
\text { Kontekstual al- } \\
\text { Khalil }\end{array}$ & $\begin{array}{l}\text { Qamus al- } \\
\text { Marbawi }\end{array}$ & $\begin{array}{l}\text { Arabic } \\
\text { Meaning }\end{array}$ & Verb \\
\hline $\begin{array}{l}\text { menjadi } \\
\text { hitam seperti } \\
\text { arang }\end{array}$ & menjadi hitam & jadi hitam ia & أسود وهي سوداء لونه كلون الفحم فهو & سود بيسود سودًا \\
\hline $\begin{array}{l}\text { 1-menjadi } \\
\text { hijau } \\
2-\end{array}$ & $\begin{array}{l}1- \\
\text { 2-Tanaman itu } \\
\text { menjadi hijau }\end{array}$ & $\begin{array}{l}\text { 1- jadi hijau } \\
2-\end{array}$ & 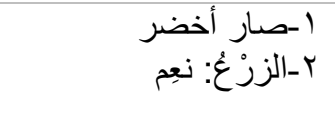 & خُضْرِر يحُضَر خَضْر \\
\hline $\begin{array}{l}\text { berwarna } \\
\text { biru }\end{array}$ & berwarna biru & $\begin{array}{l}\text { berwarna biru } \\
\text { ia }\end{array}$ & كميِ أزرق & زُرقة يزَق زرقَّا \\
\hline $\begin{array}{l}\text { menjadi } \\
\text { merah muka } \\
\text { kerana marah }\end{array}$ & $\begin{array}{l}\text { meluap } \\
\text { kemarahannya }\end{array}$ & - & تحرَّق غضباو غيظا & حمِر يحمَر \\
\hline
\end{tabular}




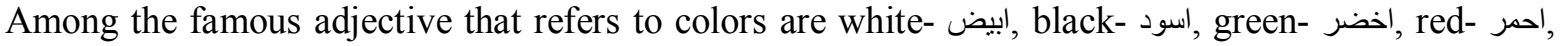

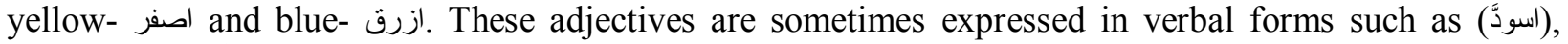

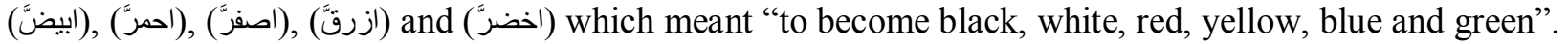

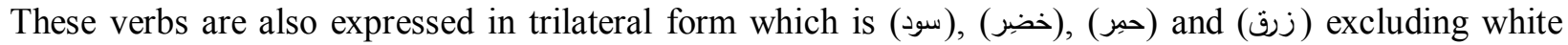
and yellow.

The table indicates that all the three dictionaries agreed to use the Malay term jadi or menjadi in order to give the meaning of "to become..." This is equivalent to the Arabic term (أصبح / صار). Hence, the meaning or interpretation of those words made by the three bilingual dictionaries are proper and meet the meaning in their original language. Nevertheless, the Arabic verbs' structures above are of single word forms while their translations were in multiple words form with the aid of the verb jadi of menjadi. Aren't there specific words or terms which are equivalent to those Arabic verbs? Nik S. K. (1997) mentioned that the verbal forms could be derived by adding the prefix 'men' to the adjectives denoting colours, e.g.:

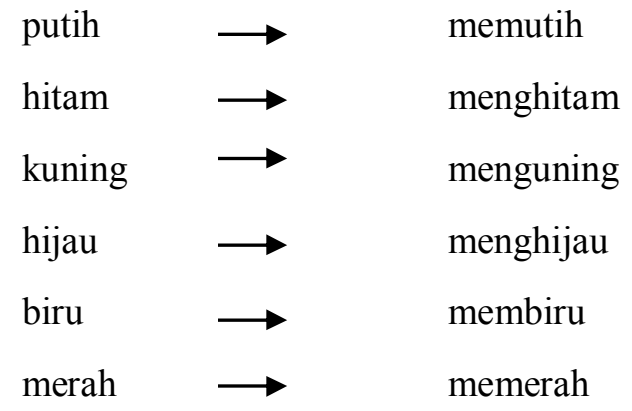

However, the translation for the verb (حمر) in those dictionary is related to anger and not directly referred to redness. It is a kind of metonymy that anger is synonymous to redness of the eyes. Hence, these words will give a clearer idea according to the context of the sentence. For example,

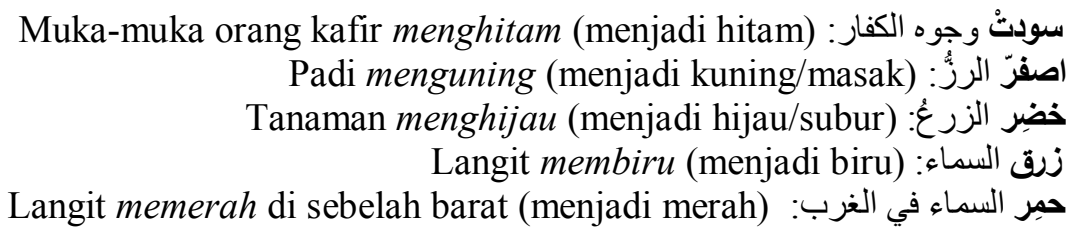

\subsection{CONCLUSION}

From the analysis above, the role of the Muslim scholars in the advancement of Malay culture and education could not be undermined. The development of Arabic Malay bilingual dictionary is an evidence to the fact that the Malay language has developed over the years despite the fact that there was a wide gap between the arrival of Islam and the production of these dictionaries. However, the dictionaries are still unidirectional, whereby Arabic is always translated to Malay. There is a need for Malay Arabic dictionary also, in order to make the existing ones bidirectional where meanings of Malay words could be translated to Arabic. This would be more useful to Malay students who are enthusiastic of Arabic language. It would assist the Malays to transfer their ideas into Arabic, thereby making it easier to translate books written originally into Arabic for the benefit of the international community especially the Arabs. Therefore, more studies and researches should be done in order to upgrade the present dictionaries in order to cover different perspectives such as specialized bilingual dictionaries. These dictionaries can cover areas like medicine, commerce, social etc. 


\section{References}

Alfa M. Salisu, et al. (2014). Arabic education in University of Ilorin, Nigeria: A review. International Journal of Education and Research. 2(10).

Al-Fairūz Abādi.(2003). Al-qāmūs al-muhịt. Beirut: Dār Iḥyā’ al-Turāth al-'Arabi.

Al-Ba'lī Badr al-Dīn. (1422 A.H.). Al-Manhaj al-Qawīm fi Ikhtișār Q Ti Dais-Sirāṭ al-Mustaqīm. Makkah al-Mukarramah: Dār 'Ālim al-Fawāid.

Akhidime, J.A.F. (1979). Contributions of the Muslim world to the science of lexicography. The Journal of Islamic Culture.

Darwish, R. (n.d). Al-Ma 'äjim al- 'Arabiyyah. Beirut: Lacmum Publications.

Fatai, O.J. (2014). Science of Arabic lexicography: A survey of its emergence and evolution. Journal of Education and Practice. 5(14).

Haywood, J.A.. (1960). Arabic Lexicography: Its History and its Place in the General History of Lexicography. Leiden: E.J. Brill

Hussein al- Habsyi. (1989). Kamus al-Kautsar Lengkap (Arab-Melayu ). Batu Caves: Thinkers Library.

Ibn Khallikan. (1961). Biographical Dictionary. (MacGuckin de Slane, Trans.). NewYork: Johnson Reprint.

Ibn Manzur. (n.d). Lisān al-'Arab. Third Edition. Beirut: Dār Ihyā’’ al-Turath al-'Arabī.

Ibrahim M., et al. (1972). Al-Mu 'jam al-Wasìt. Second edition, Istanbul: al-Maktabah al-Islamiyyah.

Inghert R.F, \& Woodward M. (n.d.) Language conflicts and political community. In Pier Paolo Giglioli (Ed). Language and Social Context: Selected readings. Baltimore \& Middlesex:Penguin Books.

Muhammad Kamal Hassan. (2004). The Muslim world in the 21st century: The Malay-Indonesian region. Journal of Islam in Asia, 1.

Muhammad Idris al-Marbawi. (1998). Qamus al-Marbawi. Fifth Edition. Kuala Lumpur: Dar al Fikr.

Nassar, H. (n.d). Al-Mu 'jam al-'Arabī: Nash'atuhu wa Tațawwuruh. Cairo: Dār Miṣr li al-Ṭibā'ah.

Nielsen, Sandro. (2010). Specialised translation Dictionaries for Learners. In P. A. Fuertes-Olivera (Ed). Specialised dictionaries for learners. Berlin/New York: de Gruyter

Nik Safiah Karim, et al. (1997). Tatabahasa Dewan. Kuala Lumpur: Dewan Bahasa dan Pustaka.

Nik Safiah Karim. (1996). Pendahuluan, Unsur Bahasa Asing dalam Bahasa Melayu. Kuala Lumpur: Dewan Bahasa dan Pustaka.

Noss R. BM. (1984). An Overview of Language Issues in South-East Asia 1950-1980. Singapore: Oxford University Press.

Osman Khalid, et al. (2006). Kamus Arab Melayu Dewan. Kuala Lumpur: Dewan Bahasa dan Pustaka.

Snedon, James N. (2003). The Indonesian Language: Its History and Role in Modern Society. Kessington: UNSW Press.

Sulaiman M. et al. (2002). Tatabahasa Melayu Mesra Pengguna. Kuala Lumpur: Utusan Publications \& Distributors Sdn Bhd.

Ya'qūb, Emil Badī'. (1981). Al-Ma'ājim al-Lughawiyyah al-'Arabiyyah. Beirut: Dār al- 'Ilmī li alMalāyīn. 